\title{
Ovarian sex cord stromal tumors: an institutional experience
}

\author{
Shruti Bhargava ${ }^{1 *}$, Jyotsna Vyas ${ }^{2}$, Adarsh Bhargava ${ }^{2}$
}

${ }^{1}$ Department of Pathology, ${ }^{2}$ Department of Obstetrics and Gynecology, SMS Medical College, Jaipur, Rajasthan, India

Received: 24 June 2017

Accepted: 24 July 2017

\section{*Correspondence:}

Dr. Shruti Bhargava,

E-mail: shrutibhargavapath@gmail.com

Copyright: (c) the author(s), publisher and licensee Medip Academy. This is an open-access article distributed under the terms of the Creative Commons Attribution Non-Commercial License, which permits unrestricted non-commercial use, distribution, and reproduction in any medium, provided the original work is properly cited.

\section{ABSTRACT}

Background: Sex cord stromal tumors are a heterogeneous group of rare neoplasms of ovary. These tumors arise from different cells of the ovary and have a fascinating variety of clinical presentations. They are mostly diagnosed on histopathology after surgical removal.

Methods: Our study aims at discussing the clinical and histomorphological spectrum of these rare tumors at a tertiary care centre.

Results: In our study 158 ovarian sex cord stromal tumors were received over a period of eight years at our institute. Out of these, the most common age group was 30 to 40 years and the chief complaint was abdominal pain and lump in majority of cases. Most common tumor histologically was Adult Granulosa cell tumor (42.4\%). There were 8 $(5.1 \%)$ Juvenile granulosa cell tumors, 31 (19.6\%) fibromas, $6(3.8 \%)$ thecomas, 14 (8.9\%) fibrothecomas, 24 $(15.2 \%)$ sertoli leydig cell tumors and $7(4.4 \%)$ sclerosing stromal tumors. We encountered one case of sex cord tumor with annular tubules.

Conclusions: Sex cord stromal tumors are uncommon ovarian tumors in Indians but have a wide range of distribution of age, clinical features and histopathological types. Since most of these have a relatively good prognosis, a high index of suspicion and thorough knowledge of clinicopathological findings is important for correct diagnosis and appropriate treatment.

Keywords: Granulosa, Sertoli leydig cell, Sex cord stromal

\section{INTRODUCTION}

Ovarian tumors are common neoplasms in women accounting for about $30 \%$ of all female genital cancers. ${ }^{1}$ However, Ovarian sex cord stromal tumors (SCST) are relatively rare tumors and account for about $5-7 \%$ of all primary ovarian neoplasms.

They are a heterogeneous group of tumors arising from cells of gonadal sex cords (Granulosa and Sertoli cells), stroma (theca and leydig cells) or fibroblasts in the ovary. ${ }^{2}$ The morphology of these tumors depends on the cell of their origin. These tumors have a fascinating variety of clinical presentations and may escape detection. ${ }^{2}$ Since sometimes the clinical features mimic those of epithelial neoplasms of the ovary, hence a clinical and histopathological correlation is must for these tumors. ${ }^{3}$ They are usually diagnosed by histopathology following surgery, due to their smaller size, lower grade of malignancy and the rarity of these tumors; they are often diagnosed by pathology following surgery. ${ }^{3}$

Conservative surgery is the primary treatment for these tumors in early stages while advanced disease requires primary or adjuvant chemotherapy. Majority of these tumors are of low malignant potential and are associated with favorable prognosis. ${ }^{4}$ In this study, we have tried to describe the clinicopathological spectrum of various sex 
cord stromal tumors encountered at our institute, which is one of the largest tertiary care institutes in India.

\section{METHODS}

We carried out this study at SMS Medical College, in the department of Pathology and Gynecology over a period of eight years from July 2009 to June 2017. All the cases of ovarian tumors diagnosed as sex cord tumors on histopathology were considered.

The clinical details of each of these were noted along with the histopathological study.

For histopathological examination, representative tissue sections were taken from the formalin fixed specimen, processed overnight in automatic tissue processor and embedded in paraffin. Then 5-micron thick sections were cut from the paraffin block and stained using Hematoxylin and Eosin stain, for microscopic examination. Various histopathological types of sex cord stromal tumors were noted on microscopy.

Thus, the demographic, clinical and histological spectrum of all the specimens of ovarian sex cord stromal tumors received in the department of pathology was studied.

\section{RESULTS}

In our study 158 sex cord stromal tumors were analyzed. The patient's age ranged from 8 years to 82 years (Table 1). Maximum number of cases was in the age range of 40-50 years.

Table 1: Age wise distribution of cases.

\begin{tabular}{|c|c|c|}
\hline Age group & No. of cases & $\%$ \\
\hline $0-10$ years & 2 & 1.2 \\
\hline $10-20$ years & 11 & 7.0 \\
\hline $20-30$ years & 21 & 13.3 \\
\hline $30-40$ years & 36 & 22.8 \\
\hline $40-50$ years & 28 & 17.7 \\
\hline $50-60$ years & 26 & 16.5 \\
\hline $60-70$ years & 23 & 14.6 \\
\hline $70-80$ years & 10 & 6.3 \\
\hline$>80$ years & 1 & 0.6 \\
\hline Total & 158 & 100 \\
\hline
\end{tabular}

As depicted in Table 2, the main complaint in majority of cases was abdominal pain and lump (81 cases), followed by menstrual irregularity in 49 patients. The signs and symptoms of excessive hormonal activity such as virilization and precocious puberty were found in 12 and 2 cases respectively. Table 3 shows the macroscopic distribution of these cases on the basis of size, laterality and gross appearance. Most of the tumors (152) were unilateral. Three cases of Granulosa cell tumor, 2 fibromas and the single case of sex cord tumor with annular tubules involved both side ovaries.
Majority of the tumors were in the size range of 5 to 15 $\mathrm{cm}$. Only two cases each of fibroma and adult granulosa cell tumors were more than $15 \mathrm{~cm}$ in size while 12 cases were smaller than $5 \mathrm{~cm}$. Grossly 87 tumors were completely solid while 71 were partly solid and partly cystic in appearance.

Table 2: Clinical presentation of cases.

\begin{tabular}{|lll|}
\hline Clinical presentation & No. of cases & $\%$ \\
\hline Abdominal pain and lump & 81 & 51.3 \\
\hline Menstrual irregularity & 49 & 31.0 \\
\hline Anorexia and weight loss & 14 & 8.9 \\
\hline Precocious puberty & 2 & 1.2 \\
\hline Virilization & 12 & 7.6 \\
\hline Total & 158 & 100 \\
\hline
\end{tabular}

Table 3: Macroscopic characteristics of sex cord stromal tumors.

\begin{tabular}{|lll|}
\hline \multirow{2}{*}{ Lacroscopic findings } & No. of cases \\
\hline \multirow{3}{*}{ Size } & Unilateral & 152 \\
\cline { 2 - 3 } & Bilateral & 6 \\
& $<5 \mathrm{~cm}$ & 12 \\
\hline \multirow{2}{*}{$\begin{array}{l}\text { Gross } \\
\text { Appearance }\end{array}$} & $5-15 \mathrm{~cm}$ & 142 \\
\cline { 2 - 3 } & $>15 \mathrm{~cm}$ & 4 \\
\hline
\end{tabular}

Table 4 depicts the histomorphological spectrum of sex cord stromal tumors. In our study, of the different subtypes of sex cord stromal tumors, most common was adult Granulosa cell tumor $(42.4 \%)$. There were $8(5.1 \%)$ Juvenile granulosa cell tumors, 31 (19.6\%) fibromas, 6 $(3.8 \%)$ thecomas, $14(8.9 \%)$ fibrothecomas, $24(15.2 \%)$ sertoli leydig cell tumors and 7 (4.4\%) sclerosing stromal tumors. We encountered one case of sex cord tumor with annular tubules.

\section{Table 4: Histomorphological spectrum of sex cord stromal tumors.}

\begin{tabular}{|lll|}
\hline Histological type of tumor & No. of cases & $\%$ \\
\hline Adult Granulosa cell tumor & 67 & 42.4 \\
\hline Juvenile Granulosa cell tumor & 8 & 5.1 \\
\hline Fibroma & 31 & 19.6 \\
\hline Thecoma & 6 & 3.8 \\
\hline Fibrothecoma & 14 & 8.9 \\
\hline Sertoli leydig cell tumor & 24 & 15.2 \\
\hline Sclerosing stromal tumor & 7 & 4.4 \\
\hline $\begin{array}{l}\text { Sex cord tumor with annular } \\
\text { tubules }\end{array}$ & 1 & 0.6 \\
\hline Total & 158 & 100 \\
\hline
\end{tabular}

\section{DISCUSSION}

The sex cord stromal tumors account for approximately $7 \%$ of all ovarian tumors. ${ }^{1}$ These have a wide age range 
of presentation and an even wider clinical and histomorphological profile. .,5 $^{1,}$

In this study, we have focused on the epidemiological, clinical and histomorphological spectrum of these rare tumors at our institute which is one of the largest tertiary care centre in India.

Out of the 158 cases of sex cord stromal tumors encountered in our study, the patient's age ranged from 8 years to 82 years with a maximum incidence in the age group of 40-50 years. This is slightly lower as compared to other studies. 6,7

The most common clinical presentation in our study was abdominal pain and lump, whereas the signs and symptoms of hormonal excess such as virilization and precocious puberty and menstrual irregularities were relatively less. This is in accordance with the available international literature. ${ }^{6-9}$

The histomorphological observations in our study are similar to other reports. ${ }^{6,7} \mathrm{We}$ observed that most of the tumors were unilateral, ranging from 5 to $15 \mathrm{~cm}$ in size. Three cases of Granulosa cell tumor, 2 fibromas and the single case of sex cord tumor with annular tubules involved both side ovaries. Grossly 87 tumors were completely solid while 71 were partly solid and partly cystic in appearance.

The histopathological spectrum of tumors in our study comprised of majority of cases of adult Granulosa cell tumor $(42.4 \%)$. Similar observation is seen in almost all studies done on ovarian sex cord stromal tumors. ${ }^{5-7}$ There were $8(5.1 \%)$ Juvenile granulosa cell tumors, 31 (19.6\%) fibromas, $6(3.8 \%)$ thecomas, $14(8.9 \%)$ fibrothecomas, $24(15.2 \%)$ sertoli leydig cell tumors and $7(4.4 \%)$ sclerosing stromal tumors. We encountered one case of sex cord tumor with annular tubules. The percentage of Juvenile Granulosa cell tumors was more than that observed by Cartault et al and Scheneider et al while similar to those reported by Haroon et al. ${ }^{4,9,10}$ However, sertoli leydig cell tumors was found to be less frequent than fibrothecoma group as compared to those in other studies. ${ }^{6,7}$ This could be due to reluctance of patients with symptoms of virilization to come for treatment due to social stigma attached.

\section{CONCLUSION}

To conclude, the sex cord stromal tumors of ovary are rare neoplasms in Indian Population. Hence a high index of suspicion and thorough knowledge of clinicopathological findings is important for correct diagnosis and appropriate treatment.

Funding: No funding sources

Conflict of interest: None declared

Ethical approval: Not required

\section{REFERENCES}

1. Rosai J. Ovary. In Rosai and Ackerman's surgical pathology. Eds. Rosai J. Philadelphia 7: Elsevier, Mosby; 2004:1649-50.

2. Young RH, Scully RE. Ovarian Sertoli-Leydig cell tumors. A clinicopathological analysis of 207 cases. Am J Surg Pathol. 1985;9:543-69.

3. Horta M, Cunha TM. Sex cord-stromal tumors of the ovary: a comprehensive review and update for radiologists. Diagn Interv Radiol. 2015;21(4):27786.

4. Cartault A, Caula-Legriel S, Baunin C, Le Mandat A, Lemasson F, Galinier P, et al. Ovarian masses in adolescent girls. Endocr Dev. 2012;22:194-207.

5. Nucci MR, Oliva E. Gynecologic Pathology. In Sex cord-stromal tumors of the ovary. Eds. Deaver MT, Oliva E, Nucci MR. Churchill Livingstone: Elsevier Churchill Livingstone;2009:457-60.

6. Haroon S, Zia A, Idrees R, Memon A, Fatima S, Kayani N. Clinicopathological spectrum of ovarian sex cord stromal tumors: 20 years retrospective study in a developing country. J Ov Can Res. 2013;6:87.

7. Sarwar S, Siddiqui N, Ather S, Hannan A, Syed AA, Zafar W. Outcomes among patients with sex cord stromal tumor of ovary: experience from Pakistan J Ayub Med Coll Abbottabad. 2014;26(3);389-92.

8. Cecchetto G, Ferrari A, Bernini G, Alaggio R, Collini P, Virgone C, et al. Sex cord stromal tumors of the ovary in children: a clinicopathological report from the Italian TREP project. Pediatr Blood Cancer 2011;56:1062-7.

9. Haroon S, Idrees R, Zia A, Memon A, Fatima S, Kayani N. Ovarian Sex Cord Stromal Tumors in Children and Young Girls-A More Than Two Decade Clinicopathological Experience in a Developing Country, Pakistan. Asian Pacific J Cancer Prevention. 2014;15(3):1351-5.

10. Schneider DT, Calaminus G, Harms D, Gobel U: Ovarian sex cord-stromal tumors in children and adolescents. J Reprod Med. 2005;50:439-46.

Cite this article as: Bhargava S, Vyas J, Bhargava A. Ovarian sex cord stromal tumors: an institutional experience. Int J Reprod Contracept Obstet Gynecol 2017;6:3924-6. 